\title{
過給機駆動用ラジアル排汽タービンの非定常流特性に関する研究* (タービン性能予測に与える脈勤波形の影響)
}

\author{
小 西 奎 二*1, 吉 識 晴 夫*2
Characteristics of Radial Inward-Turbines for Exhaust Gas Turbochargers under Nonsteady Flow Conditions \\ (Effects of Waveforms on Prediction of Turbine Performance)
}

\author{
Keiji KONISHI and Haruo YOSHIKI
}

\begin{abstract}
This paper deals with effects of waveforms on predicting performances of a radial turbine for turbochargers under pulsating flows. The extensive unsteady tests were conducted with several pulse shapes and pressure amplitudes over a pulse frequency range from 10 to $70 \mathrm{~Hz}$ produced by a disk -type pulse generator rig. Five kinds of pulse shapes were simulated for exhaust gas flows from diesel engines. The time-mean method and the quasi-steady flow analysis were carried out to predict the turbine characteristics by using the steady flow turbine performance. As the results, the following points are made clear. For most turbine running conditions, the quasi-steady flow analysis is satisfactorily valid regardless of whether the turbine is effected by the waveform, amplitude and frequency. It is considered that the turbine under pulsating fow conditions works along the curves of steady flow performances except for windage states. The time-mean method predicts the power output fairly well, but grossly overestimates the mass flow rates according to the waveforms.
\end{abstract}

Key Words: Supercharger. Radial Turbine, Turbocharger Turbine, Unsteady Flow, Pulsating Flow, Quasi-Steady, Waveforms

\section{1. 緒}

動圧駆動タービンの性能予測を行う場合，それに影 響を与える流れの大きな因子として脈動周波数，振幅， 波数の三つが挙げられ、これらがタービン性能にどの ように関与してくるのかを明らかにする必要がある。

これらに関してはすでに多くの報告，たとえば文献 (1)〜(6)がある. 著者らも前報 ${ }^{(7)(8)}$ での流れの基本 となる正弦波波形を用いた場合の流量・出力特性に与 える脈動周波数と振幅の影響について，時間平均法お よび準定常法を用いて報告した。しかし，波形の影響 については高圧・大流量の空気流の波形変化が困難な

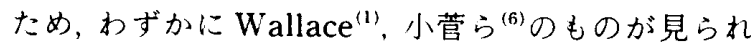
る程度である。しかし，実機の波形に対応してなく，振 幅の影響についても記されていないなど，まだ十分な 結果が得られていない.

本研究では，このような過給機用ラジアル排気夕ー ビンの非定常流性能を予測寸るための基礎研究とし て,タービン単体性能に与える脈動流との関係を調べ た。さらにその基礎として本報においては，円盤形脈

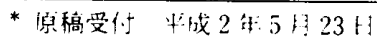

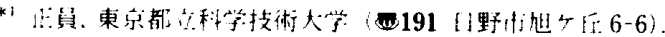

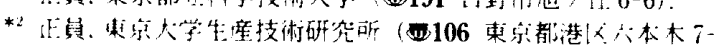
22-1).
動流発生装置を用いて脈動波形を種々変化させ，その 影響について定常流性能を用いた時間平均法および準 定常法の 2 解析方法により研究したものである.

$$
\text { 主な 記 号 }
$$

$$
\begin{aligned}
& A_{o}: \text { 送入孔基準面積 } \mathrm{m}^{2} \\
& A_{v}: \text { 回転弁開口面積 } \mathrm{m}^{2} \\
& f: \text { 脈動周波数 } \mathrm{Hz} \\
& L: \text { 出力 } \mathrm{kW} \\
& M: \text { 質量流量 } \mathrm{kg} / \mathrm{s} \\
& N: \text { 回転速度 } \mathrm{rpm} \\
& N^{*}: \text { 修正回転速度 }=N / \sqrt{T_{o 1}} \\
& P: \text { 圧力 } \mathrm{Pa} \\
& P_{o 1}: \text { タービン入口全圧 } \mathrm{Pa} \\
& R: \text { 膨張比 }=P_{o 1} / P a \\
& T: \text { 温度 } \mathrm{K} \\
& T_{o 1}: \text { タービン入口全温度 } \mathrm{K} \\
& T q: \text { トルク } \mathrm{N} \cdot \mathrm{m} \\
& V: \text { 流速 } \mathrm{m} / \mathrm{s} \\
& \varepsilon_{p}: \text { 圧力波形率 }[\text { 式 }(4)] \\
& \theta: \text { 速度振幅比 } \\
&(8) \\
& \text { 字 }
\end{aligned}
$$


$e:$ 実測值

$t m$ : 時間平均法特性

$q:$ 準定常法特性

$m:$ 時間平均値

* : 修正状態

$1:$ タービン入口

4：動翼入口

5：動翼出口

$a:$ 大気状態

\section{2. 実験装置およひ方法}

空気源と脈動流発生装置を組合せた既報(7)(8) とほほ 同一の実験装置によって空気運転した。その主要部を 図 1 に示す.

脈動流発生装置は，図 2 に示すような円盤形回転弁 を用いた，図 2 は，二つの固定円盤の間を通風孔を持 った回転円盤が流れを断続することにより脈動流を発 生させるものである。供試タービンが二送入孔形式で あるため, 円盤は $180^{\circ}$ の位置に二つの送入孔を有し， 各基礎孔径 $60 \mathrm{~mm}$, 円盤外径 $312 \mathrm{~mm}$ のものである.

したがって，円盤 1 回転につき同位相の 2 パルスを 発生し、タービンを駆動する。脈動波形の変化は, 固定 円盤と回転円盤の開口部形状を種々変化させて行う. 円盤の開口部形状の代表例を図 3 に示士. 円盤の回転 速度は,インバー夕制御の電動機により駆動し, 脈動 周波数を変化させる. 周波数の設定誤差は, $10 \mathrm{~Hz}$ の ときにおいても最大約 $0.3 \%$ 以内である。振幅の調節 は,バイパス弁の開閉によって行い, 定常流に近い状 態から部分的に逆流の生じる範囲まで連続可変でき る。これによって任意の波形および振幅を持った種々 の流れを得た。なお，作動流体の外部に対する漏九は， 駆動プーリ側のエヤーシール部分のみで，ほとんど無 視できる、また，固定円盤と回転円盤間の漏れは平均 流の大きさに影響を与えるが, 最大振幅時の流れに対 して全く問題ない程度のものである。

タービン修正回転速度は，定常・非定常流実験を通 じて $N^{*}=800$ のみとした. 定常流実験は回転弁を固定 して同装置で行い，また，流速や全温度など変動值測 定系の検定のため, 非定常流実験の前後に定常流実験 を適宜行った。

定常流実験は負荷を変化させる通常の方法により, また非定常流実験は圧縮機の出口を絞った全負荷状態 を基本にし，膨張比もほぼ一定としたときのものであ る. 非定常流実験における波形変化は, 先に報告 ${ }^{(7)(8)} し$ た正弦波に準じたものを基本波形として考え，本報で は実機に対応した模擬波形として 5 種類変化きせた。
さらに, 同一波形について脈動周波数を $10 \sim 70 \mathrm{~Hz}$ と し，おのおのの周波数に対して振幅を 10〜13 点変え て行った。実験は, 各波形について時間平均脰張比を ほほ定として周波数を変化させ，回転弁のバイパス 弁により振幅を設定した後, 修正回転速度 $N^{*}=800$ となるよう流量調節して実験条件を設定した。

\section{3. 脈动流の代表例}

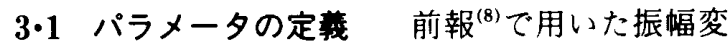
化に着目した速度振幅比や圧力振幅比では，波形の違 いを考慮できないので，あらたに圧力波形率 $\varepsilon_{p}$ を以

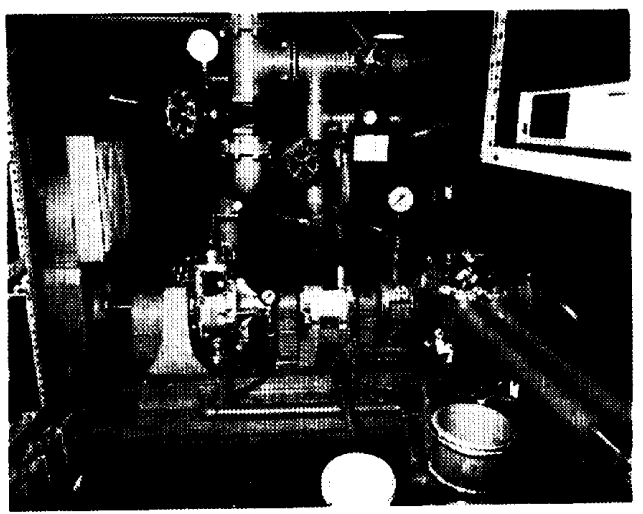

図 1 実験装置主要部

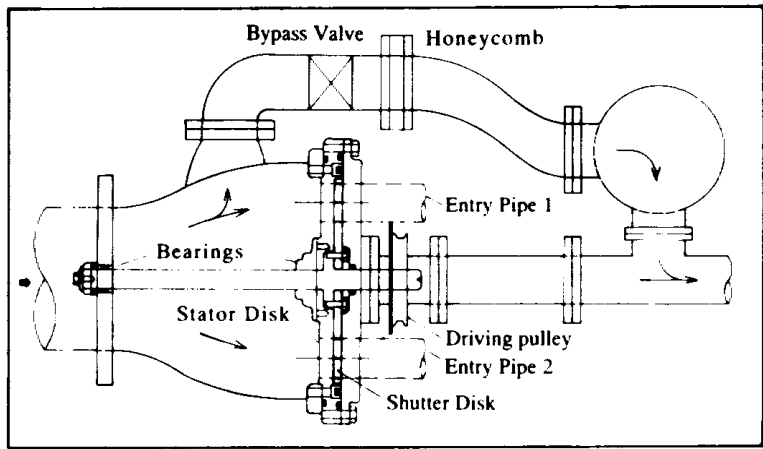

図 2 円盤形脈動流発生装置

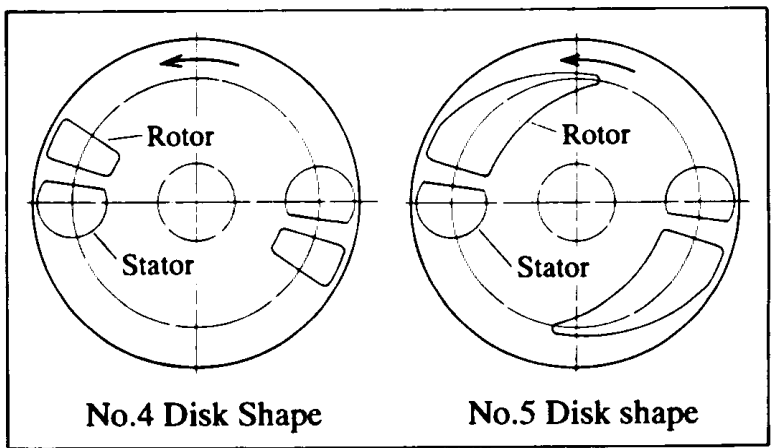

図 3 以盤開口部形状代表例 
下のように定義した。これは Benson ら (4)が提案して いるもので，基本的には式（1）に示すように圧力振幅 の実効值を平均圧力で除したものであり，電気工学で 波形率と呼ばれているものと同じ考えである.ただし， 実効值としては，内燃機関などで用いられている平均 有効圧力の考え方を取り入れて，一周期の脈動流がな す仕事量を定常流に置き換えた場合の值を想定し，実 効值本来の形である直流成分を含めたものとした。す なわち。

$$
\varepsilon_{p}=\frac{\text { 压力波形の } \mathrm{rms} \text { 值 }}{\text { 压力変動の時間平均值 }}
$$

圧力波形率 $\varepsilon_{p}$ を算出するために, タービン入口で測 定した全圧をフーリェ級数で近似する。

$$
P_{01}(t)=P_{01 m}+\sum_{n=1}^{\infty}\left(a_{n} \cos n t+b_{n} \sin n t\right)
$$

このとき $P_{01}(t)$ の $\mathrm{rms}$ 值は

$$
P_{01}(t)_{\mathrm{rms}}=\left[\left(P_{01 m}\right)^{2+} \frac{1}{2} \sum_{n=1}^{\infty}\left(a_{n}^{2}+b_{n}^{2}\right)\right]^{1 / 2}
$$

となる，さらに式(1)のままでは， $\varepsilon_{p}$ の值が小さく変 化の傾向を表しにくいうえに，大気圧までの膨張を基 準にしたエネルギー量を考えるため, 平均圧力から大 気圧を減じたものを基準に考え，次式で表される $\varepsilon_{p}$ を定義した。

$$
\varepsilon_{p}=\frac{\left[\left(P_{01 m}-P_{a}\right)^{2+} \frac{1}{2} \sum_{n=1}^{k}\left(a_{n}^{2}+b_{n}^{2}\right)\right]^{1 / 2}}{\left(P_{01 m}-P_{a}\right)}
$$

ここで 5 次以降は微小であるので $k=4$ 次までとし た.

また同样に流速を基準にとれば速度波形率を定義で きるが，実用を主として考え，本報では压力波形率を 用いた。

$3 \cdot 2$ 各波形の代表例 一般に，一つの排気過給 機で多シリンダを受け持つ場合, タービン入口部では, 排気波形が重畳されピーク值を多数持った波形とな る.この場台，脈動周波数は高くなるが，逆に振幅は平 滑され流饥の非定常性は弱まるものと思わ机る。また, 前報(7/(8)によって、タービン性能に大きな影響を与え る流れの因子は振幅であることが明らかにさられてい るので, 最大振幅を持つ脈動流を想定し, 単シリンダ からの流札を基本として考え，以下のような波形変化 を行った。

各波形の代表例を図 4～8に示す. 回転弁の回転角 に対して，タービン入口部の全圧 $P_{01}$, 全温度 $T_{01}$, 流 速 $V_{1}$, 動翼入口, 出口の全压 $P_{04}, P_{05}$, ならびに軸卜 ルク $T q$ の諸量を表す。また，送入管断面積を基淮に とった弁開口面積変化を弁回転角に対して併せて表示 してある。
これらの実験条件は，修正回転速度 $N^{*}=800$, 脈動 周波数 $f=10 \mathrm{~Hz}$ におけるバイパス弁をほほ全閉とし た最大振幅のものである，ただし，空気源の制約から バイパス弁を全閉にしても得られる最大振幅比は同一 ではない。

$3 \cdot 2 \cdot 1$ 波形 1 の代表例 波形 1 の代表例を図 4 に示す。波形 1 は，円盤開口部形状が円と円を組合せ た最も基本的なものであり，円盤の回転角に対する開 口部面積は三角形に近いものとなる。得られた波形も ロータリ弁に準じたものであるが，立上りがやや急こ う配になっており，膨張波も比較的滑らかに減速して いるものである。

以下の供試波形は，機関からの排気吹出しによる急 激な管内压力および流速の増加を考えて, 波形の立上 りがすべて急峻になるようにした。そのため，固定側 円を図 3 に示すように一部ふさいで割円とし，さらに 回転側も弁開位置での形状を同様とし，そのうえで開 口部形状を適宜変えて希望の波形とした。

$3 \cdot 2 \cdot 2$ 波形 2 の代表例 図 5 に示すように波形 2 は，急速な立上り後，ゆるかに減速し，低圧部の

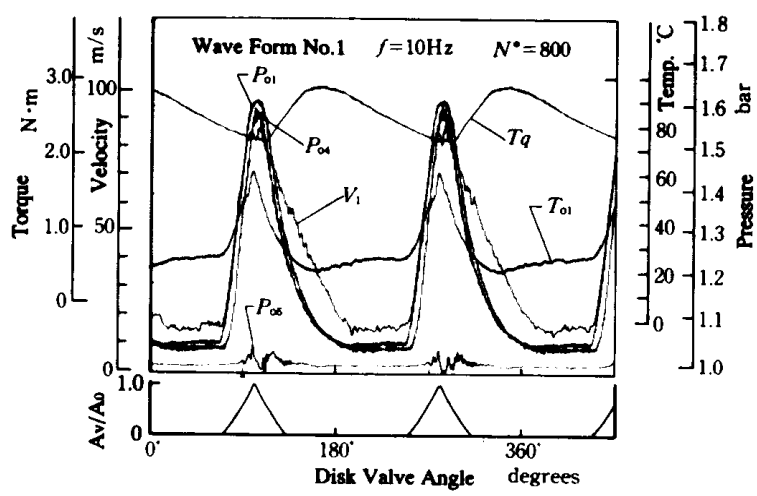

$\left(i=10 \mathrm{~Hz} . \theta=0.966 . \varepsilon_{p}=1.376\right)$ 図 4 波形 10 代表例

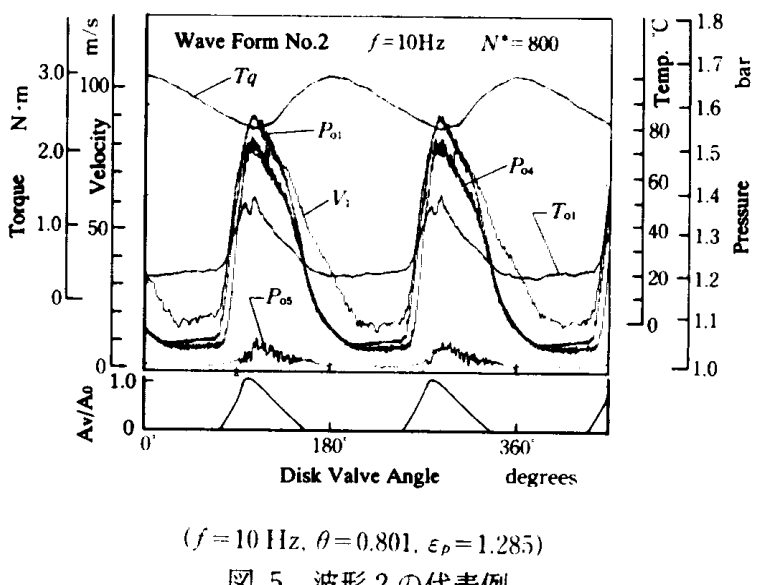

図 5 波形 2 の代表例 
長い三角波となるようにしたものである．流れの締切 時間が短くなり, 得られる最大膨張比もいくぶん小さ くなっているが, 比較的実機関の排気に近い流れが得 られている。

$3 \cdot 2 \cdot 3$ 波形 3 の代表例 図 6 に示す波形は，高 圧部の期間を長くした，いわゆる台形波もしくは方形 波を模したものである。

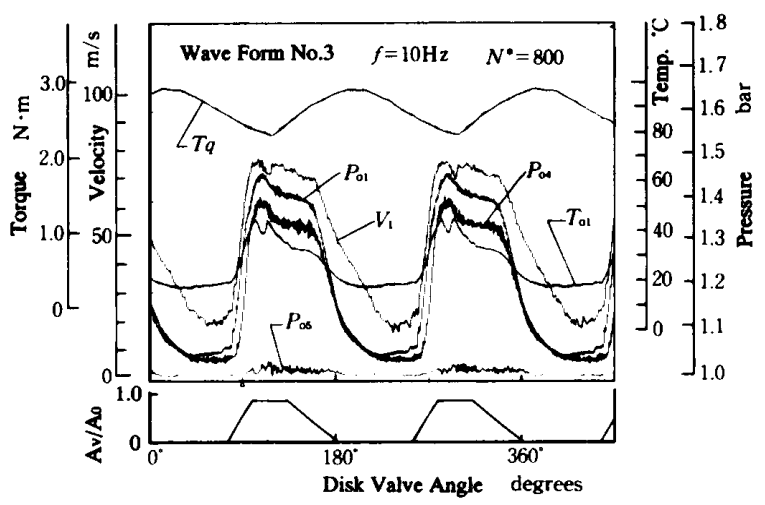

$\left(j=10 \mathrm{~Hz}, \theta=0.669 . \varepsilon_{p}=1.209\right)$

図 6 波形 3 の代表例

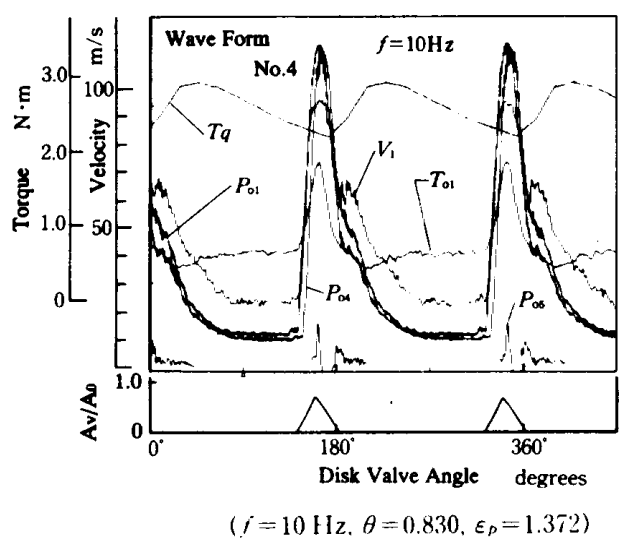

図 7 波形 4 ○代表例

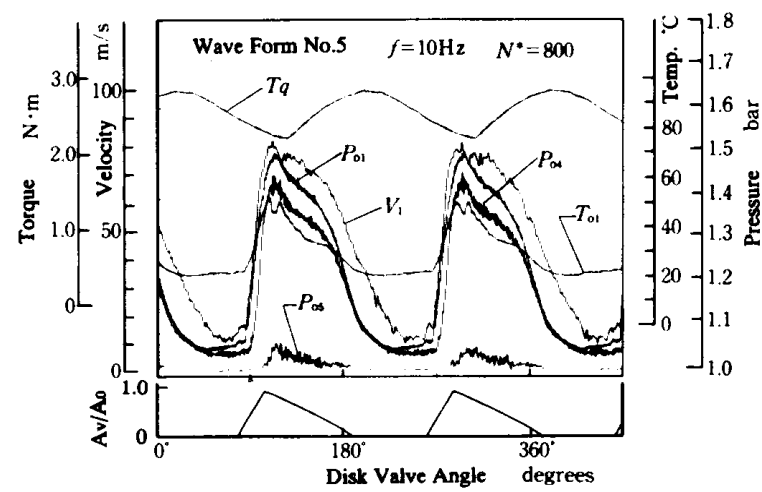

$\left(f=10 \mathrm{~Hz}, \theta=0.7 \mathrm{H}, \varepsilon_{p}=1.21 \%\right)$

図 8 波形 5 の代表例
$3 \cdot 2 \cdot 4$ 波形 4 の代表例図 7 の波形 4 は，最大 振幅が得られるように弁の開口時間を極力短くし，圧 縮，膨張とも急激な変化を与え，先鋭化したパルス状 の波形とした。

$3 \cdot 2 \cdot 5$ 波形 5 の代表例図 8 に示す波形 5 は， 以上の結果をふまえてなるべく実機の排気波形に対応 した形となるものとした。

\section{4. 結果および考察}

定常流性能曲線は，既報(7)(8)で用いたものと同一で ある。これを基礎にして時間平均法，および準定常法 によるタービン性能予測を行い, その成立程度に与え る波形の影響について検討した。本報では，計測器に よって得られた実測値を真の值とし，前記 2 法によっ て得られた值とを比較することによってその成立程度 を評価し流量, 出力值とも修正状態とした。

つぎに、前報で用いた振幅変化に着目した速度拡幅 比 $\theta$ と 3 章で定義した压力波形率 $\varepsilon_{p}$ との関係の一例 を図 9 に示寸。この関係は, タービン個々の内部流動 抵抗により，また同一タービンにおいても周波数ごと に多少異なるなど直接の関数関係にはないが、同一の 速度振幅比 $\theta=0.67$ について, $\varepsilon_{p}$ の值を比べると, 波 形 4 は $\varepsilon_{p}=1.343$, 波形 $1: 1.293$, 波形 $2: 1.250$, 波 形 $3: 1.209$, 波形 $5: 1.206$ となる.

このことより，先鋭な波形 4 は同一の速度振幅比に 対し圧力波形率 $\varepsilon_{p}$ が大きくなり，非定常性の強い流 れといえる。逆に台形波もしくは方形波に準じた波形 3は比較的穏やかな波形ということになる。したがっ て， $\varepsilon_{p}$ は振幅を加味し，波形のひずみも表すことので きるパラメータと考えられる。

\section{$4 \cdot 1$ 時間平均法による性能予測}

$4 \cdot 1 \cdot 1$ 流量特性 図 10～12に，波形をパラメー タとした時間平均法による流量子測を、波形率 $\varepsilon_{\rho}$ に

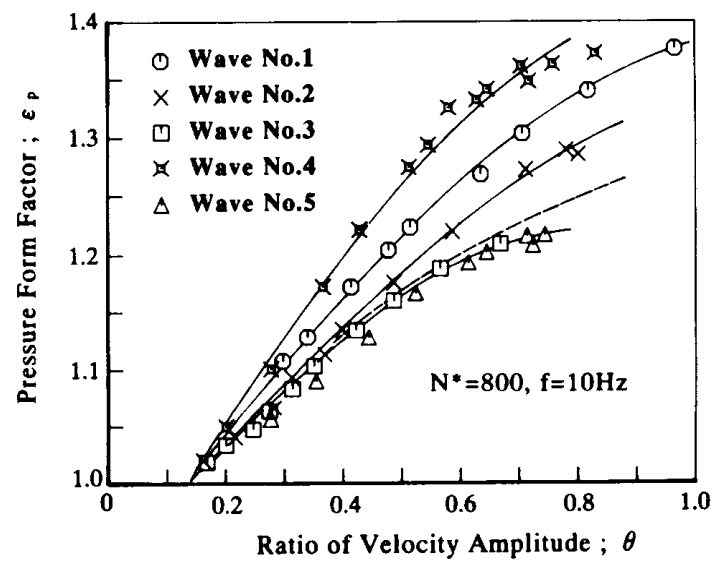

図 $9 \theta$ と $\varepsilon_{p}$ の関係 $(f=10 \mathrm{~Hz})$ 
対する流量比 $M_{t m} / M_{e}$ の関係で示す。図 10 は $10 \mathrm{~Hz}$, 図 11 は $30 \mathrm{~Hz}$, 図 12 は $50 \mathrm{~Hz}$ の結果である。なお, 図 10〜12 中の破線は，正弦波による既報 ${ }^{(7)}$ の結果を， また実線は, $10 \mathrm{~Hz}$ の実験点在最小二乗法により結ん だお抢よその傾向を示す。

流量予測に対する波形の影響は， $f=10 \mathrm{~Hz}$ では明 らかに波形の違いとして認められるが，f=30 Hzに なると明確な差が少なくなり，f=50 Hzにおいてはほ とんど差異は認められなくなる。大略の傾向として， 各波形とも流量比は， $\varepsilon_{p}$ の二乗に比例した傾向を示 し，各波形に対する比例定数は，図 9 で求めた $\theta$ に対 する $\varepsilon_{p}$ の並びと同順序で大きくなる，すなわち，波形 の影響が明確に認められる図 10 において, 同一の予 測䛊差, 例えば $10 \%$ の誤差を生じる波形の $\varepsilon_{p}$ を比較 すると，波形 4 が最も大きくつづいて波形 1 ，つぎに 波形 2 となり，つづいて少し非定常性が弱まり波形 3 、 5 が同程度で小さくなる。ロータリ弁による正弦波に 準じた基本波形は，波形 3 と波形 2 の間に位置する。

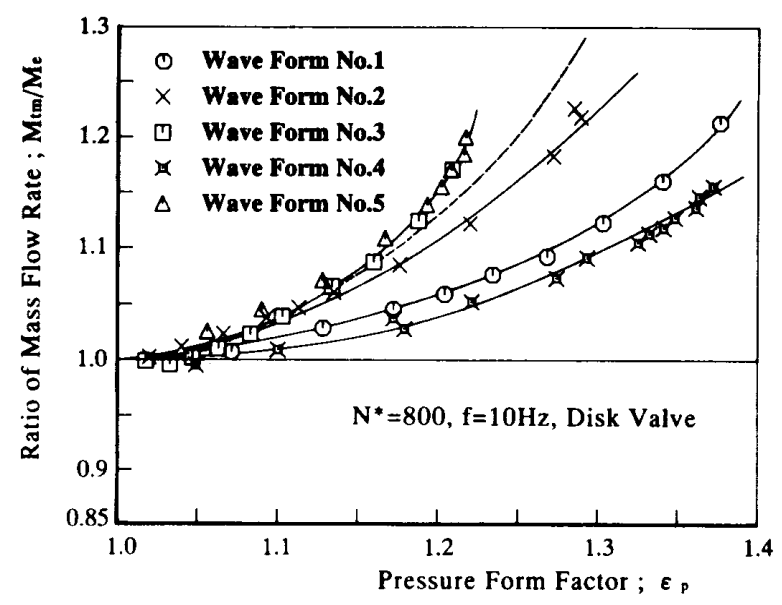

図 10 時間平均法による流量予測 $(f=10 \mathrm{~Hz})$

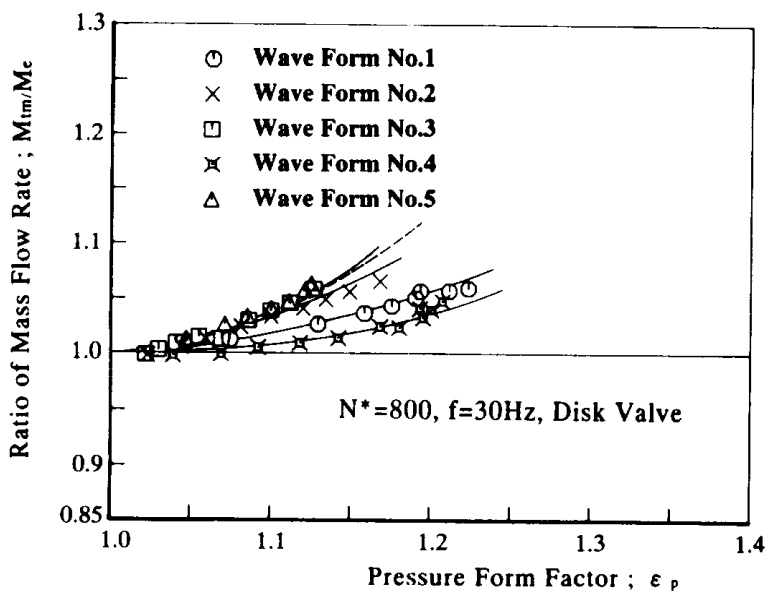

図 11 時間平均法汇上万流望予測 $(f=30 \mathrm{~Hz})$
また，同一の $\varepsilon_{p}$ で比較すると各波形の非定常性に 占める $\theta$ による速度成分の影響を表していると考え られる。すなわち，供試波形図から波形 4 は振幅変化 は大きいが, 平均流速も大きいため速度振幅比は小さ くなる。また実験条件として同一膨張比を設定してい るため $M_{\mathrm{l}}$ はほほ同じ值をとるが, 流れの慣性によ り圧力変化ほど流速は変化せず, 平均流速の大きい波 形 4 は $M_{e}$ が大きくなる.このために同一の $\varepsilon_{p}$ で比較 したとき非定常性の強い波形 4 は流量比が小さくな る.

図 11 の $f=30 \mathrm{~Hz}$ になると，流量予測に対する波形 への依存性は減少してくる。さらに, 図 $12 の f=50$ Hzになると波形への依存性はほとんどなくなり，波 形 3 の結果に収机んする傾向を見せる.

また，脈動周波数の影響は，いずれの波形において も顕著でない。このことは既報(7)の結果と同一である。 $f$ が高くなると一定の波形(波形 3 ) に近づき，予測精 度が向上する傾向を見せる。この原因は，予測精度に

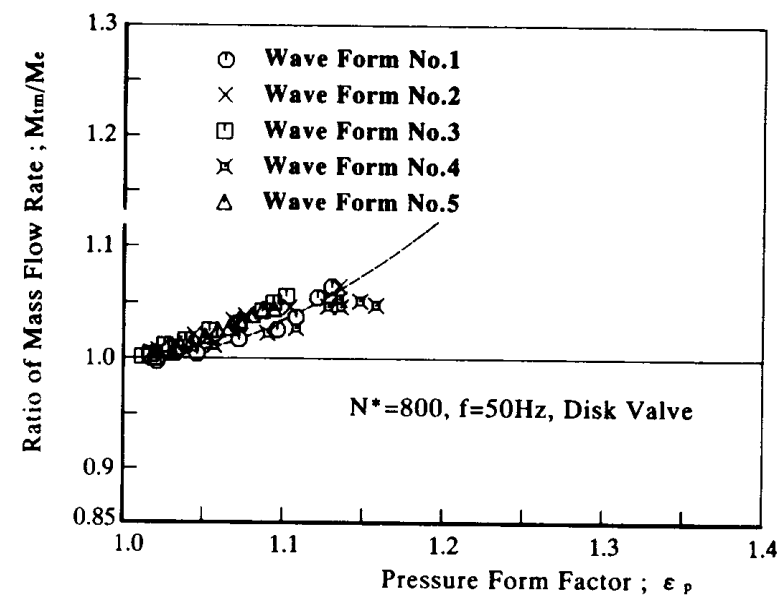

図 12 時間平均法による流量予測 $(f=50 \mathrm{~Hz})$

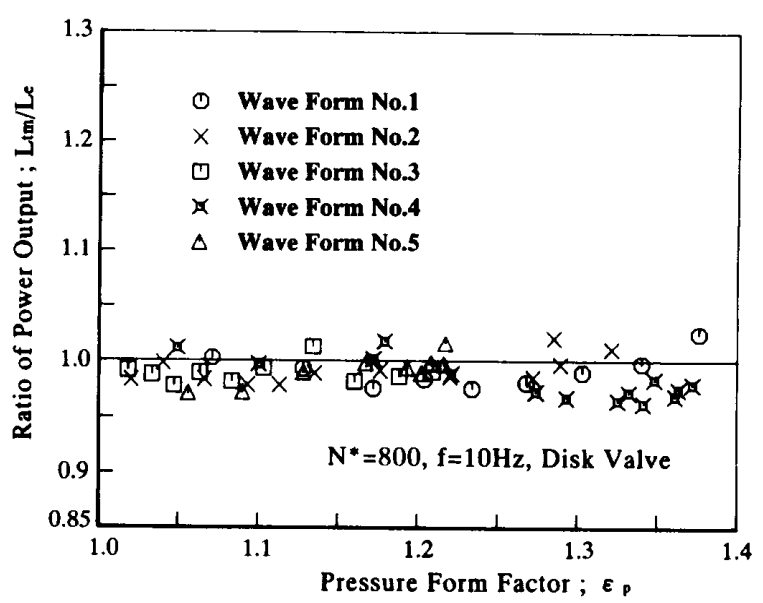

図 13 時間平均法に上る出力予測 $(f=10 \mathrm{~Hz})$ 
最も影響を与える流れの因子は振幅と考えられ，周波 数が高くなると流体の慣性によって非定常性は残る が、流れは平均流に変動成分が重畳した程度の連続し た定常流成分の多いものとなる。それゆえ，高い周波 数領域では波形の違いが少なくなり，穏やかな波形 3 に近づくものと思われる。

$4 \cdot 1 \cdot 2$ 出力特性 図 13 は, 時間平均法による出 力予測結果である。流量特性と同様に, 波形をパラメ 一夕として圧力波形率 $\varepsilon_{p}$ に対する出力比の関係を表 寸. 出力比は, トルク検出器によって得られた測定平 均値と軸受損失の和を真の值 $L_{e}$ とし,これに対する 予測值 $L_{t m}$ から算出した，図は割愛しているが周波数 が高くなっても同様の傾向を示す，基本波形による既 報(7) とほほ同様に圧力波形率および振幅による顕著な 影響は見られない。ことことは，脈動周波数，振幅およ び波形の変化を与えても時間平均法による出力予測結 果には大きな影響を生じないことを表している。すな わち，非定常流下でも時間平均タービン出力 $L_{e}$ は， 脈動流の周波数, 振幅, 波形変化によらず膨張比と修

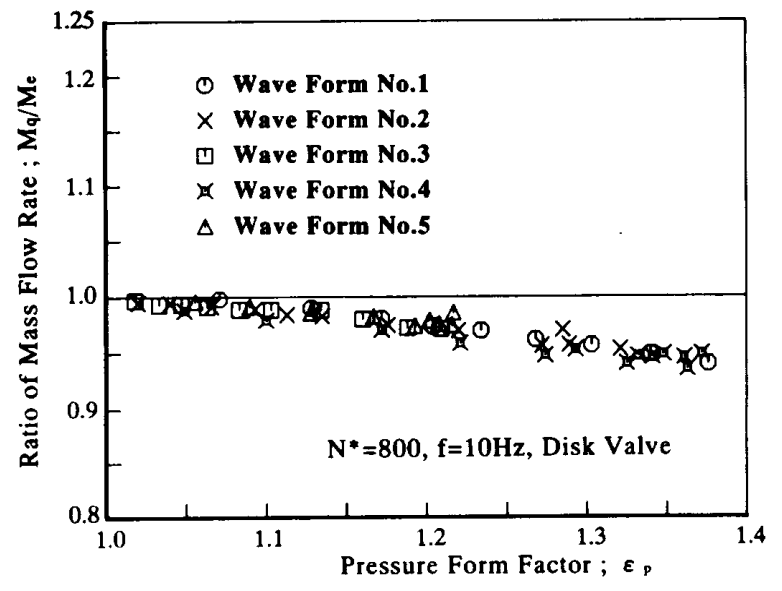

図 14 準定常法に上る流量予測 $(f=10 \mathrm{~Hz})$

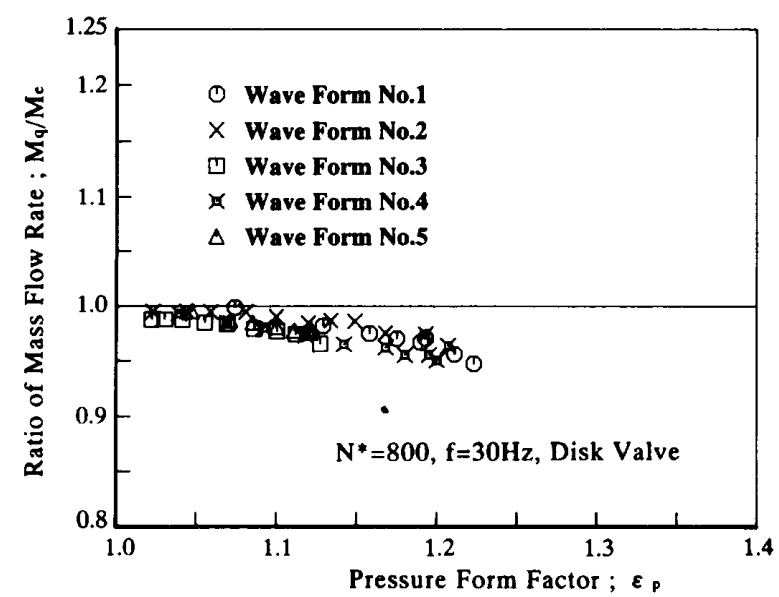

図 15 準定常法による流量予測 $(f=30 \mathrm{~Hz})$
正回転速度を与えればほほ同一となる。

なお，先の流量予測と考え併すと，タービン出力は 不変でも流量は減少することを意味する。この原因は, 非定常流下のタービンは, 圧力変動の平均值より高い 圧力成分によって大きな仕事を得ており，その分流量 は少なくてよいものと考えられる。

\section{$4 \cdot 2$ 準定常法による性能予測}

$4 \cdot 2 \cdot 1$ 流量特性 図 14〜17 は, 準定常流仮定を 用いた脈動流下のタービン流量予測結果である，時間 平均法による流量予測と同様に各周波数ごとに，波形 をパラメータとして圧力波形率 $\varepsilon_{p}$ (および $\theta$ )に対す る流量比 $M_{q} / M_{e}$ の関係について表す.

図 14〜16より明らかなように大略の傾向として,

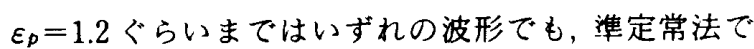
求めた值 $M_{q}$ は実測値 $M_{e}$ を高精度で見積もることが できる，さらに $\varepsilon_{p}$ が大きくなるにつれて $\varepsilon_{p}$ に比例し てわずかに過小評価の傾向を示す。波形による予測精 度の差異はほとんど認められないので, 同図から波形 の影響を厳密に論ずるのは困難である.

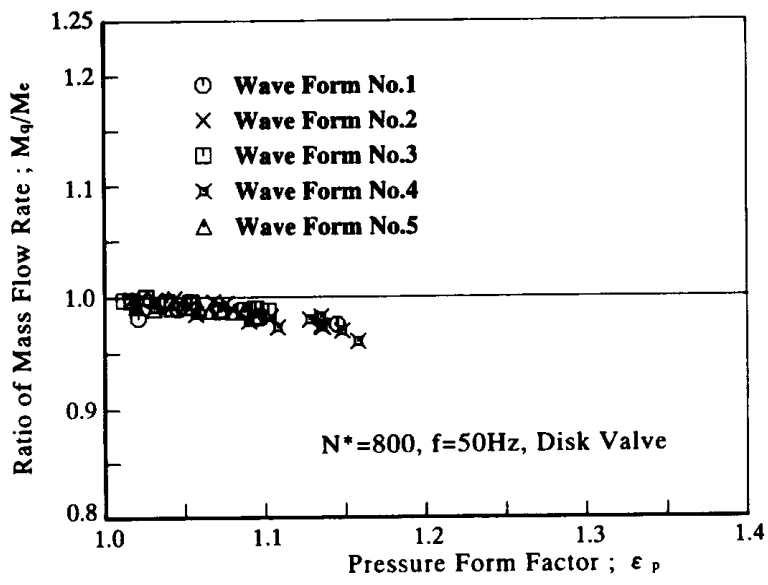

図 16 準定常法による流量予測 $(f=50 \mathrm{~Hz})$

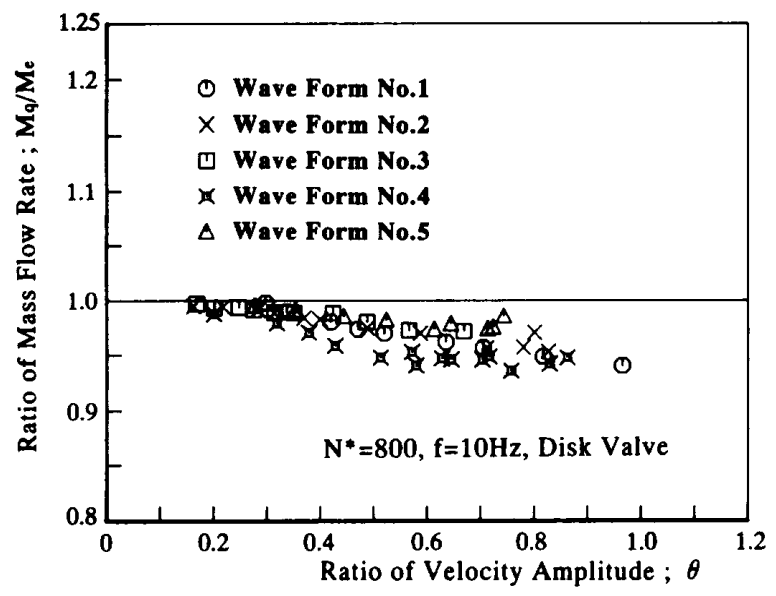

図 17 流量予湘の $\theta$ による表示 (準定常法, $f=10 \mathrm{~Hz}$ ) 
なお,図 17 は $f=10 \mathrm{~Hz}$ における図 14 の結果を速 度振幅比 $\theta$ に対して表したものである. $\varepsilon_{p}$ に対して $\theta$ は振幅のみの関数である.同一の速度振幅比例えば $\theta$ $=0.7$ につて見るとわずかではあるが， $\varepsilon_{p} へ の$ 依存 性,すなわち, 流量予測に対する一種の波形の影響を 表しているものと考えられる。したがって、ひずみの 大きい波形 4 が予測愦差が大きく，つついて，波形 1 ， 2,3 および波形 5 と図 9 で求めた非定常性の強い波 形の並びが認められる。

つぎに, 準定常法解析においても脈動周波数への依 存性はほとんど見られない. $f$ の増加にしたがって予 測精度が良くなるのは, $4 \cdot 1 \cdot 1$ 項で考察したように脈 動流自身の振幅が減少するためと思われる。

345 点に達する広範囲な実験を通して，予測誤差は 最大でも約 5 〜 $6 \%$ 籍囲にある。この值は基本波形 を用いた既報 ${ }^{(8)}$ の最大でも $5 \%$ を超えないという結果

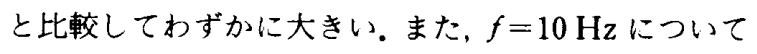
みると基本波形では速度振幅比 $\theta$ の影響をほとんど 受けなかったのに対し、図 14 では各波形とも $\varepsilon_{p}$ の影

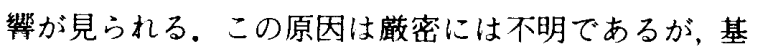

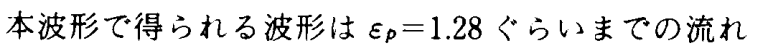
であり，また図17より，わずかに流量予測に対する波 形の影響が表れていることが考えられる。ささらに, 変 動波形の一周期に占めるウインディッジ以下の領域な どの影響のためと思われる。

以上のことより全体として, タービン性能予測に与 える波形の影響はほほ無視できるものと考えられる。 すなわち，タービン性能予測に対する集定常流仮定は 成立すると考えて大きな問題はない。言い換えれば， いずれの波形においても，ウインディッジ状態を除い て脈動流下の瞬時のタービン流量特性は, 定常流性能 曲線に浻って作動していると考えてよい。

4・2・2 出力特性図 18〜20は，準定常法による 出力予測結果である. 圧力波形率 $\varepsilon_{p}$ に対する出力比 の関係を波形をパラメータとして $f=10,30,50 \mathrm{~Hz}$ について表す、結果のばらつきは軸受損失の評価詿差 による $L_{e}$ の不正確さが主因と思われる。

各波形とも周波数が高くなれば予測誤差は振幅の減 少により少なくなるが, 波形抢よび脈動周波数による 影響は顕著でない，全体として，圧力波形率 $\varepsilon_{p}$ が大き くなれば過小評価の傾向を示すが，最大でも10\%程 度である.この值は，先の流量特性に比較していくぶ ん大きい.この原因は，既報(8)で述心゙たように定常流 性能曲線におりるウインディッジ状態での出力特性の 膨張比 $\left(R_{L}=1.086\right)$ が流星特性 $\left(R_{M}=1.037\right)$ に比較し て大きいためと思われる。本研究では，ウインディッ
ジ以下の膨張比のタービン仕事をすべて零とおいたた めに，圧力波形率の高い波形および領域で見積誤差が 大きくなったものと考えられる。

以上のことを総合的に判断して, 非定常流下の夕一 ビン性能は，出力特性においても，ウインディッジ状 態を除いてほほ定常流性能曲線に浻って作動している

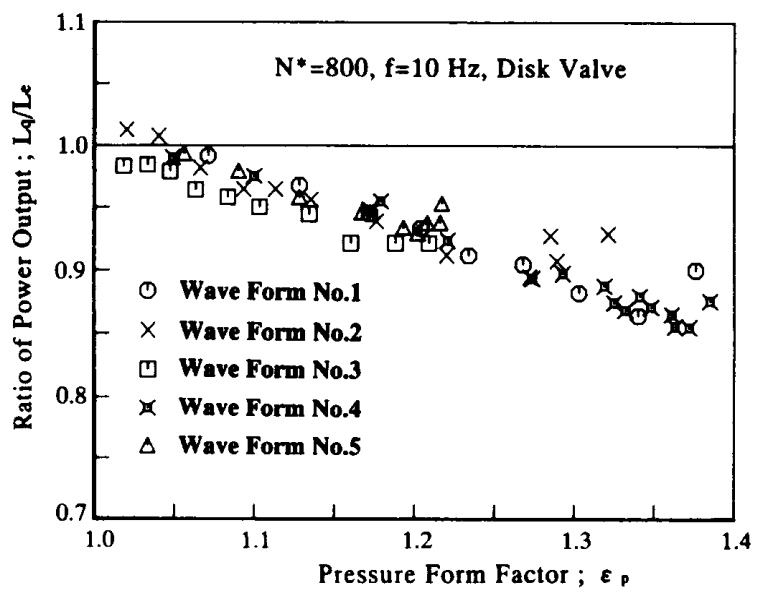

図 18 準定常法に上る出力予測 $(f=10 \mathrm{~Hz})$

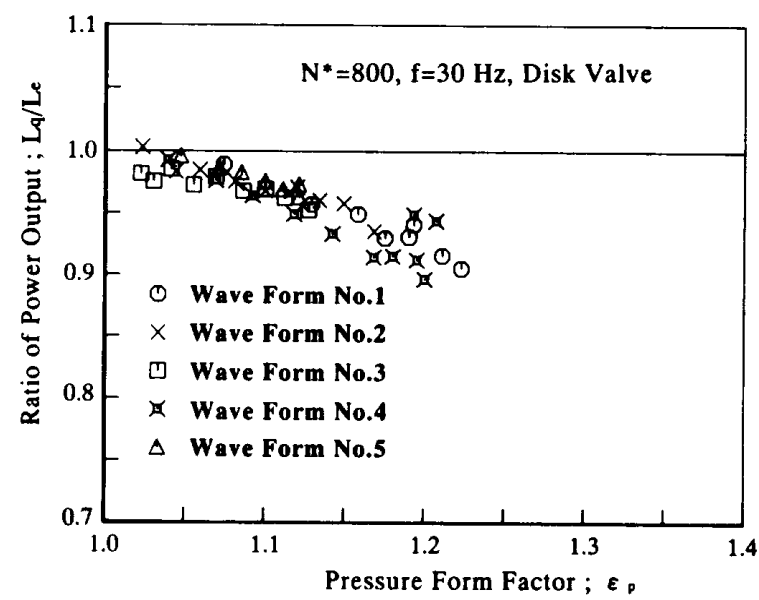

図 19 準定常法に上る出力予測 $(f=30 \mathrm{~Hz})$

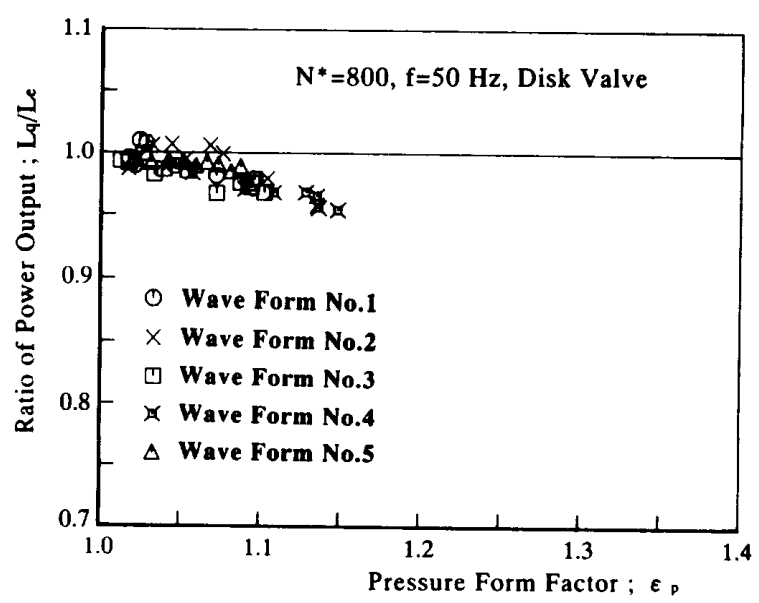

図 20 準定常法に上る出力予湘 $(f=50 \mathrm{~Hz})$ 
と考えられる。したがって，先の流量特性と併せて考 えると定常流性能の良いタービンは, 非定常流性能も 良いといえる。このことは脈動流下におけるタービン の設計指針を与える基本的なものとして考えてよい.

\section{5. 予測に対する適用限界}

本報で検討した 2 解析方法を実際のタービン性能予 測に用いる場合, 両解析とも脈動周波数の影響はほほ 無視できる，時間平均法による性能予測では，波形の 影響は低周波数域において流量の面で強く受けるが， 振幅の影響は平均膨張比として取扱うので定常流性能 曲線に準じた作動範囲となり大きな問題は生じない。 淮定常法性能予測では，波形の影響はほほ無視できる が, 振幅(膨張比変動幅)の影響については留意が必要 である.すなわち，準定常法の場合には，振幅変化は瞬 間膨張比として取扱うため通常得られている定常流性 能曲線の範囲を超える恐れがあり,これが予測精度に 悪影響を与える。特に，タービンが低膨張比の作動域 で使用される場合には重要な問題となってくる。すな わち, 夕ーボ機械の特有な作動領域として流量・出力 とも零と考えられるウインディッジ状態がある。これ 以下の膨張比では，通常定常流性能曲線自体が得られ ておらず，またタービンがどのような挙動をしている かも明らかにされていない。したがって，準定常法を タービン性能予測に適用する場合，この領域を除いて 考えるのが現時点では賢明と思われる。

このことは本質的には定常流性能曲線に起因する問 題かとも考えられるが，この領域を評価できないのは 準定常法自身の持つ一つの欠陷とも思われる，それゅ え, 準定常法によってタービン性能予測を行う場合, 膨張比がウインディッジ以下の領域を長期間占めるよ うな機関の作動状態に適用する場合は注意が必要とな る、特に出力予測の場合には，ウインディッジ状態の 膨張比が高いためその影響を強く受ける。

しかしながら、タービンがウインディッジ状態に遭 遇するような機関の作動域は，低回転速度で高負荷運 転されるごく一部の限られた範囲と考えられる。また， 実際に過給機が使用される場合，常用機関回転速度も 高く, 1 台の過給機で多シリンダを受け持つ形式が多 い。それ内之，压力変動は平滑されて平均流成分の多 い流机となるため本実験条件より緩やかなものと考え られ、このことに起因する大きな問題は生じないもの と思わ机る。

\section{6. 結}

タービン性能に与える波形の影響について, 時間平 均法および準定常法により調べた結果，以下のような 結論を得た。

（1）準定常法による流量 - 出力性能予測は, 波形, 振幅および脈動周波数によらずほほ成立する。すなわ ち,タービンは, 脈動流下でもほほ定常流性能曲線に 沿って作動していると考えてよい。

（2）以上のことから定常流性能の良いタービンは 非定常流性能も良いといえる。このことは脈動流下に おけるタービンの設計指針の基本となる。

（3）ウインディッジ状態は, 定常流性能曲線にお いても特殊な作動領域であり, 準定常法性能予測に悪 影響を与える。

（4）波形の影響は，時間平均法による流量予測で 低周波数領域において強く現れるが，その他の場合に は無視できる。

（5）振幅の影響は，両予測性能に対して最も大き な影響を与える因子として作用する。

（6）脈動周波数の影響は，両予測性能に対して顕 著でなく無視してよい.

（7）流量予測は準定常法により，出力予測は時間 平均法によれば, 高精度では非定常流特性を予測でき る.

（8） 圧力波形率は，脈動流の振幅を加味し波形の ひずみを考虑した，脈動流を記述できる因子となる。

最後に, 東京都立大学工学部熱機関研究室および東 京大学生産技術研究所の方々に種々ご協力を睗ったこ とを記して深く謝意を表す。

\section{文献}

(1) Wallace. F. J. and Blair. G. P.. ASUE Paper. 65-GTP $-21(1965) .1$.

(2) Wallace. F. J.. Adgey. J. .I. and Blair. G. P.. Prnc Inst. Mech. Eng., 184. Pt. 1(1969-70). 183.

(3) Benson, R. S. and Scrimshaw. K. H.. Proc. Inst. M/ch. Eng., 180. Pt. 3 J paper 23(1965-66), it.

(4) Benson. R. S.. SAE Paper. NoT40739(1974-9). 1.

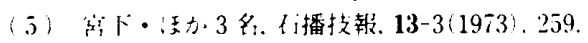

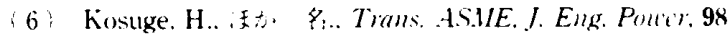
$-1(1976), 53$.

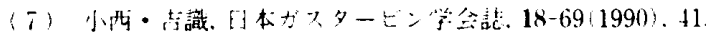

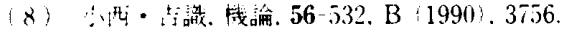

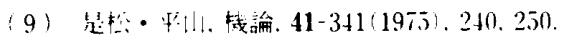

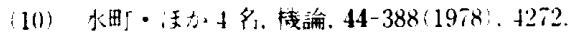

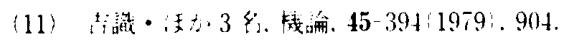

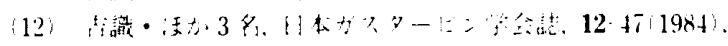
41. 